\title{
www.smokehaz.eu - a review of the evidence on smoking and lung health
}

\author{
Brian Ward
}

Affiliation: European Respiratory Society, EU Affairs, Brussels, Belgium.

Correspondence: Brian Ward, ERS Office, EU Affairs, 49-51 Rue du Treves, 1040, Brussels, Belgium. E-mail: brian.warddersnet.org

0

@ERSpublications

ERS publishes review on the health hazards of smoking, 50 years on from the US Surgeon General's landmark report http://ow.ly/x0X43

This year marks the 50th anniversary of the landmark report on smoking and health, released by US Surgeon General Dr. Luther Terry [1]. It was the first US government advisory committee report linking smoking and ill health. The report was a wake-up call for America and the world. The Advisory Committee, headed up by Terry, concluded in 1964 that:

"Cigarette smoking contributes substantially to mortality from certain specific diseases and to the overall death rate."

"Cigarette smoking is causally related to lung cancer in men; the magnitude of the effect of cigarette smoking far outweighs all other factors. The data for women, though less extensive, point in the same direction." "Cigarette smoking is the most important of the causes of chronic bronchitis in the United States, and increases the risk of dying from chronic bronchitis and emphysema."

"Male cigarette smokers have a higher death rate from coronary artery disease than non-smoking males..."

This rigorous scientific report laid the foundation for tobacco control efforts in the USA and around the world.

This year sees the welcome continuation of the Terry tradition of rigorous science with the launch of a project of the Tobacco Control Committee of the European Respiratory Society (ERS): a scientific review on the health hazards of smoking (SmokeHaz). The SmokeHaz concept was championed by Prof. Christina Gratziou as part of her three-year work plan as chair of the Tobacco Control Committee. It is a collaboration between the ERS and the UK Centre for Tobacco and Alcohol Studies (UKCTAS). The two organisations joined forces, and together with the European Lung Foundation (ELF), produced a website aimed at policy makers, primarily focused on the respiratory health hazards associated with smoking. The research was carried out by the UKCTAS with funding from the ERS. The website was developed by the ELF. The ERS Tobacco Control Committee had oversight of the project.

Following approval by the Executive Committee of the ERS, the website is now available online at www.smokehaz.eu. The research focuses on respiratory health hazards in the first instance; however, this could be extended to other health hazards in future if funding and further collaboration opportunities arise.

The SmokeHaz review is very much in the spirit of the Surgeon General's report which made substantial use of a meta-analysis performed by statistician William G. Cochran, who was then a professor of statistics at Harvard University. According to SCHUMACHER et al. [2], as an author of the report, Cochran followed the major steps for a modern systematic review, including a meta-analysis based on data on individual participants in seven large, prospective cohort studies that had been initiated in the 1950s. Cochran used modern state-of-the-art statistical methods, although the presentation of the results with confidence intervals was rarely done at that time. It is widely recognised that the Surgeon General's report on smoking

Received: April 152014 | Accepted: May 152014

Conflict of interest: B. Ward is an employee of the European Respiratory Society.

Copyright @ERS 2014 


\section{TABLE 1 www.smokehaz.eu recommendations}

1) To prevent uptake of smoking it is important to develop more smoke-free areas in public, to increase the price of cigarettes and remove smoking from media and internet content; this will progressively reduce morbidity and mortality from smoking within the next two decades and into the future

2) Comprehensive local, national and European Union interventions against smoking should be further strengthened, including sustained health promotion media campaigns, large pictorial warnings and plain packaging on tobacco products, and tobacco use should be phased out

3) To reduce the burden of tobacco-induced respiratory disorders it is important to encourage all current smokers to quit in order to reduce morbidity and mortality from smoking over the next two decades and beyond [6]

4) Smoking cessation treatment (counselling in combination with drugs) is one of the most cost-effective interventions in medicine; it should be used more widely and its cost should be reimbursed completely Education and training in cessation of tobacco use should be included in the curricula of all health professionals and medical students [7]

5) The UK model, with public smoking cessation clinics for every 150000 people in the population and reimbursement of smoking cessation therapy, could be a model for other European countries.

6) The obligations and guidelines of the World Health Organization Framework Convention on Tobacco Control should be further implemented across Europe [8]

7) Current smoke-free laws protect adults in the workplace and entertainment venues; however, these laws do not prevent exposure in the womb, in the home or in private vehicles, where levels of toxins can be very high

Legislation to protect new-borns and children is needed to prevent harm to exposed children

More detailed information on the burden, cost and areas for action surrounding tobacco and lung health can be found in the European Lung White Book sections on tobacco smoking and passive smoking [9].

and health is important for public policy, however, the importance of this report for meta-analysis is often overlooked and also warrants attention.

The www.smokehaz.eu review was officially launched on May 8, 2014 in Athens, Greece in the presence of the President of the ERS, Peter Barnes and the Greek Health Minister. The event was held under the auspices of the Hellenic Presidency of the European Union and it brought together leading tobacco control figures from across Europe. President Barnes spoke at the event and clarified that the aim of the www.smokehaz.eu website is to provide a one-stop web platform assessing the relationship between active and passive smoking and a range of specific health outcomes, particularly focusing on lung health. $\mathrm{He}$ emphasised that robust methods were used to gather together all of the available scientific studies that provided an unbiased account of the true relationship between smoking and health. Furthermore, he encouraged the Greek authorities to use the evidence provided by the ERS to improve tobacco control in the country.

According to Housmann [3] there were three elements that contributed to the success of the Surgeon General's report: "1) The legitimacy and authority of the surgeon general's office; 2) the meticulous accumulation and aggregation of scientific evidence characterizing the report that resulted in the claim that a causal relationship existed; and 3) the widespread campaign that publicized the findings of the report."

The ERS has taken heed of these elements and is confident that the scientific standing of the ERS and the legitimacy of the Hellenic Presidency of the European Union, the meticulous work of the UKCTAS researchers and the Tobacco Control Committee, the public launch of this project in a country with one of the highest prevalences of smoking in Europe - together with an easily accessible website format - will ensure that www.smokehaz.eu will be a successful and useful resource for all those interested in evidencebased action on tobacco.

A recent report in the Journal of the American Medical Association estimates that the decline in smoking has prevented 8 million deaths since 1964, more than half of them among people under the age of 65 years [4]. However, we have a lot more to do in order to reduce the death toll, particularly in Europe where it is estimated that almost 700000 people still continue to die each year due to smoking [5]. www.smokehaz.eu makes a number of recommendations on actions that can be taken (table 1). It is hoped that www.smokehaz.eu with its evidence based results and recommendations will encourage policymakers to take much-needed action going forward to reduce deaths from tobacco.

\section{References}

1 National Library of Medicine. Profiles in Science. The Reports of the Surgeon General. The 1964 Report on Smoking and Health. http://profiles.nlm.nih.gov/ps/retrieve/Narrative/NN/p-nid/60 Date last updated: April 10, 2014. Date last accessed: April 10, 2014.

2 Schumacher M, Rücker G, Schwarzer G. Meta-analysis and the Surgeon General's report on smoking and health. N Engl J Med 2014; 370: 186-188.

3 Housman M. Smoking and health: the 1964 Surgeon General's report as a turning point in the anti-smoking movement. Harvard Health Policy Review 2001; 2: 118-126. 
4 Holford TR, Meza R, Warner KE, et al. Tobacco control and the reduction in smoking-related premature deaths in the United States, 1964-2012. JAMA 2014; 311: 164-171.

5 European Commission. Proposal for a Directive of the European Parliament and of the Council on the Approximation of the Laws, Regulations and Administrative Provisions of the Member States Concerning the Manufacture, Presentation and Sale of Tobacco and Related Products. Brussels, European Commission, 2012. Available from: http://ec.europa.eu/health/tobacco/docs/com_2012_788_en.pdf

6 Tønnesen P, Carrozzi L, Fagerström KO, et al. Smoking cessation in patients with respiratory diseases: a high priority, integral component of therapy. Eur Respir J 2007; 29: 390-417.

7 Nardini S, ed. Smoking Cessation. European Respiratory Monograph. Sheffield, European Respiratory Society, 2008. Available from www.erspublications.com/content/smoking-cessation

8 World Health Organization. Framework Convention on Tobacco Control. www.who.int/fctc/en/ Updated 2014. Date last accessed: April 10, 2014.

9 Gibson GJ, Loddenkemper R, Sibille Y, et al., eds. European Lung White Book. Sheffield, European Respiratory Society, 2013. Available from: www.erswhitebook.org 